\title{
Assessment of Gmelina, Danta Solid Wood and Plywood Hive Types for Beekeeping
}

\author{
${ }^{*}$ AKINBI, OJ; ${ }^{1}$ ADEDUNTAN, SA; ${ }^{1}$ TOYINBO, EO; ${ }^{2}$ ALAMU, OT \\ ${ }^{* 1}$ Forestry and Wood Technology Department, Federal University of Technology, Akure. P.M.B. 704 Akure. Nigeria. \\ ${ }^{2}$ Forestry Research Institute of Nigeria, Ibadan P.M.B 5054, Nigeria \\ *Correspondent Author Email: akinbilanre3@gmail.com; Tel: +2348063058707 \\ Other Authors Email: seuntoyinbo2003@yahoo.com; tomniyialamu@yahoo.com; sundayadeduntan@gmail.com
}

\begin{abstract}
The study was carried out to compare the performance of wood hive types and plywood hive types in three different vegetation types between June 2018 and May 2020 in Akure South local Government of Ondo State, Nigeria. A total of eighteen (18) Kenyan Top Bar hives made from Danta, Gmelina and plywood were constructed at six (6) each per wood types. Two (2) each of Danta, Gmelina and Plywood hives were installed in three locations: Natural Forest, Plantation forest and cocoa farmland. The rate of colonization of each hive was evaluated at $6,12,18$ and 24 months after installation in the field. The results revealed that plywood hive type was not colonized in the natural forest throughout the period of study while Danta and Gmelina each recorded 50\% colonization at the end of the experiment. In plantation forest, each of the Plywood and Gmelina hives recorded 50\% colonization at 24 months after installation while bees in Danta hives absconded before 24th months after installation. In cocoa farmland, Gmelina recorded 100\% colonization at 24 months, Danta recorded 50\% colonization at 24 months and plywood accounted for $100 \%$ colonization at 24 months after installation. An improvement was recorded in the colonization performance at 12,18, 24 month after installation of hives. Plywood hives installed in the cocoa farmland and plantation accounted for higher colonization percentage than natural forest.
\end{abstract}

\section{DOI: https://dx.doi.org/10.4314/jasem.v25i4.22}

Copyright: Copyright $(92021$ Akinbi et al. This is an open access article distributed under the Creative Commons Attribution License (CCL), which permits unrestricted use, distribution, and reproduction in any medium, provided the original work is properly cited.

Dates: Received: 14 February 2021; Revised: 26 March 2021; Accepted: 12 April 2021

Keyword: Beekeeping, Colonization, Danta hive, Gmelina hive and plywood hive

Apis mellifera is native to tropical Africa and has been observed to have a higher degree of preference for nesting in white and yellow coloured wood cavities in the wild in Nigeria (Adedeji and Aiyeloja, 2014). Kenya top-bar hive (KTBH) has been proved to be most suitable for domestication of honeybee because it is easy to use, cheap and simple to construct by beekeepers or local carpenters (Tessega, 2009; FAO, 1990). Honeybees preferred to nest in cavities of trees like Gmelina arborea, Vitex doniana, Vitex ferruginea, Adansonia digitata, Ceiba pentandra, Bombax buo- nopozense Pycnanthus angolensis etc. Brown coloured wood trees' cavities were not usually used in the wild for nesting probably because of the chemical composition of brown wood (Aiyeloja, and Adedeji, 2014). The honeybee colony performance in terms of strength and productivity is measured by the total area of comb in the colony containing stored honey, pollen and brood, adult bee population, weight per bee and the colony nest cavity volume ratio (Vaudo et al. 2011). A survey of available literature revealed the paucity of documented information on the suitable woods for beekeeping in Nigeria. In particular, no information could be found on the nexus between the natural wood species cavities preferred in the wild and test of such woods for suitability of modern beekeeping in Nigeria. Evidences abound to suggest such link for using Cedar and Pine woods as honeybees hive materials in America and other temperate regions having tropical forests (Warre, 2007). Apismellifera has been globally managed and more appreciated in other continents than Africa where it originated. (Ruttner, 1988;Franck et al., 2000). Toon and Kail woods that are widely used in Asia for beehives construction are synonymous with Cedar and Pine respectively (Noatay, 2002). However, many literatures in Africa had recommended the use of brown woods for beekeeping on the account of their durability without any scientific linkage approach between the woods preferred in the wild and the brown woods recommended (Adedeji and Ayeloja, 2014). The long standing relationship between Honeybees and trees before the interference of man was enough for the bees to have known what is desirable for them. Therefore, it becomes imperative that a thorough knowledge of its physical and chemical properties should precede choice and selection of wood species for beekeeping. 
The trend of indiscriminate felling in most of our natural forest in southwest of Nigeria has posed a serious threat on forest products that led to some economic tree species going to an extinction (FAO, 2009). This has made some economic timber woods scarce and costly in the timber market. Hence, the consideration today for an exotic tree species (Gmelina arborea), because of it fast growing rate and short gestation period has been grown in some plantation around us in southwest Nigeria and are of high demand for both timber wood and plywood products. It has been recorded in the recent research findings that Gmelina arborea was adopted as suitable honeybee hive nesting in Imeko Ogun state of savannah belt and sparse forest suitable for beekeeping (Adedeji and Aiyeloja, 2014). But there is need to compare Gmelina arborea with other tree species in the rainforest zone of Nigeria. This study aimed at examining the preferred hive types among Gmelina arborea solid wood, Danta solid wood and plywood; and also to assess colonization performance of different bee hives type among the three locations in the study area.

\section{MATERIALS AND METHODS}

Study Area: The research was conducted in Akure South Local Government Area in Ondo State (latitude $7^{0} 15^{\prime} 25.679$ ' ' N, longitude $5^{0} 12^{\prime} 20.848^{\prime}$ ' $\mathrm{E}$ and $370 \mathrm{~m}$ above the sea level) between June 2018 and May 2020.. Akure experiences a warm humid tropical climate, with two distinct seasons, the rainy and dry season. The rainy season lasts for about seven months, April to October while the dry season five months November to March respectively. Akure and its environs experience a frequent annual rainfall of over $1500 \mathrm{~mm}$ with a short August break. The average temperature is about $22^{\circ} \mathrm{C}$ during harmattan (December to February) and $32^{\circ} \mathrm{C}$ in March. Three locations are selected for the study with a coordinate as FWT Gmelina plantation in FUTA (latitude $7^{0} 18$ '29'N and longitude 508'6'E), Cocoa farm in Ago-Store community before Owena (latitude $7^{0} 12$ '43"N and longitude 502'44'E) and PSP 29 Akure forest reserve Owena (latitude $7^{0} 1$ ' $12^{\prime}$ 'N and longitude $5^{0} 1$ ' $\left.44^{\prime \prime} \mathrm{E}\right)$. Hives were left to be colonized by natural swarm of honeybees for a period of 24 months. A total of eighteen (18) Kenyan Top Bar hives made of Danta, Gmelina, and plywood were constructed at six (6) per each hive types while two (2) each were installed in three locations: Natural Forest, Plantation forest, and Cocoa farm land. Bee wax was considered to be the best bait materials to attract swarm and they are strips on the top bar inside each hive (Eaton, 2006).

Evaluation of colonization was carried out on the solid wood hives and $6 \mathrm{~mm}$ plywood hives by natural swarm of honeybees.

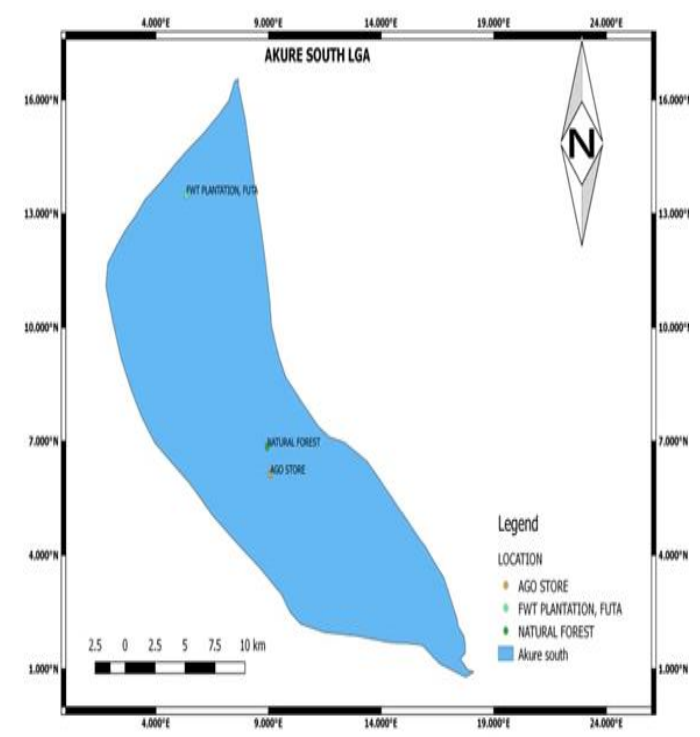

Fig 1: Map showing the study area

Data on colonization was collected in each location and on each hive type at 6, 12, 18 and 24 months after hive installation using rating in Table 1. Percentage was set as parameter to measure performance of preferred hives in each location at various levels of honeybee colonization. Descriptive statistics was employed to analyze data and results were presented using tables and figures.

\begin{tabular}{|c|c|}
\hline Colonization status & $\begin{array}{l}\text { Percentage } \\
\text { assigned }\end{array}$ \\
\hline No colonization & 0 \\
\hline $\begin{array}{l}\text { One (1) Hive colonised but } \\
\text { absconded }\end{array}$ & $25 \%$ \\
\hline One (1) Hive colonised & $50 \%$ \\
\hline $\begin{array}{l}\text { Two (2) Hives colonised but } 1 \\
\text { absconded }\end{array}$ & $75 \%$ \\
\hline Two (2) hive colonized per location & 100 \\
\hline
\end{tabular}

\section{RESULTS AND DISCUSSION}

In the natural forest, no hive was colonized at 6 months after installation. At 12 months after installation, 50\% each of the hives made of Danta and Gmelina woods were colonized but bees in Gmelina hive absconded before the end of the 12th month. At 18 and 24 months, $50 \%$ each of hives made of Danta and Gmelina woods were colonized. However, hives made of Polywood were not colonized throughout the period of 24 months (Fig. 1).In plantation forest, at 6 months after installation, $50 \%$ each of the hives made of the three wood materials were colonized with bees; but bees in Poly wood hives absconded before the end of the 6th month. At 12, 18 and 24 months, 50\% of all the hives made of Danta, Gmelina and Poly woods were colonized with the exception of Danta wood hive 
where bees absconded the hive before the end of the 24th month (Fig. 2).

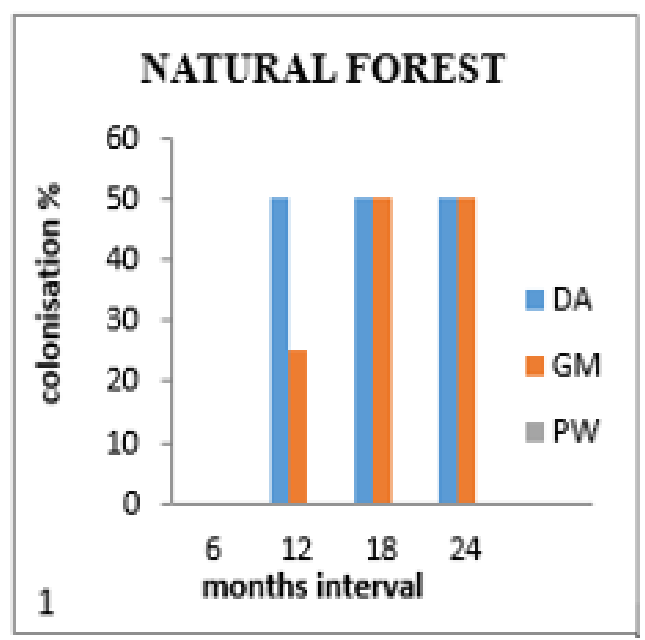

DA: Danta, GM: Melina, PW: plywood

Fig 1: Colonization of different hive types in three land use areas

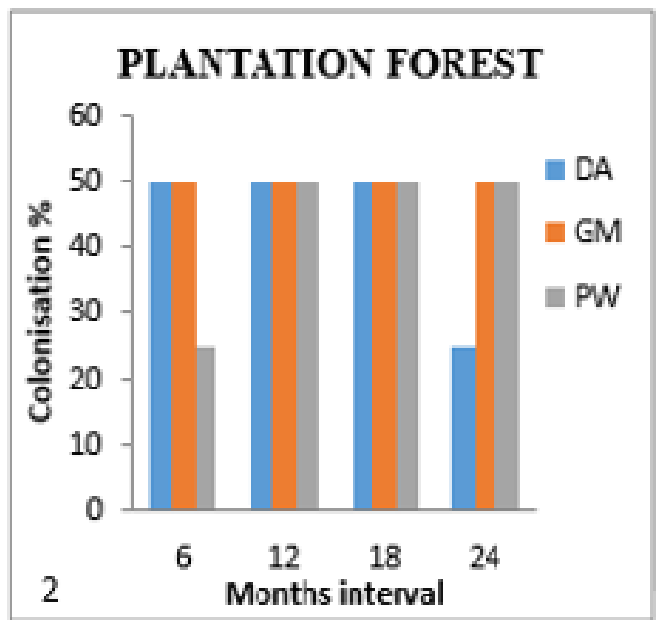

DA: Danta, GM: Melina, PW: plywood

Fig 2: Colonization of different hive types in three land use areas

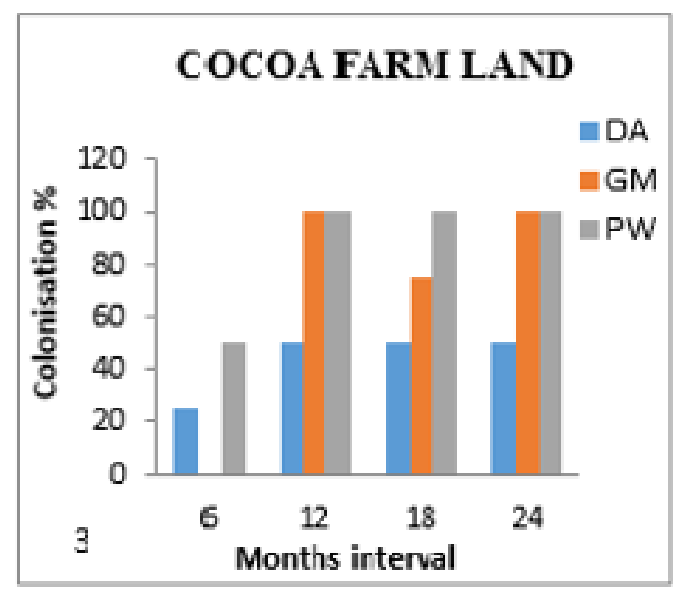

DA: Danta, GM: Melina, PW: plywood

Fig 3: Colonization of different hive types in three land use areas
The results in Cocoa farmland showed that $50 \%$ of Danta wood hive were colonized within the first 6 months but the bees left the hives before the end of the 6 th month. However, the hives were re-colonized within the next 6 months and remained colonized throughout the period of study. Gmelina wood hives were not colonized at the beginning of the study but $100 \%$ colonization was recorded at 12 months after installation. At 18 months, bees in one of the Gmelina wood hives absconded but the hive was re-colonized to maintain $100 \%$ colonization at 24 months. Only $50 \%$ of the plywood hives were colonized with bees at 6 months but increased to $100 \%$ colonization at 12,18 and 24 months after installation (fig. 3).

The study revealed poor colonization of hives by natural swarm of honeybees in the three locations for the first six (6) months after installation. This may be as a result of high humidity of the environment during the period of study that fell within the rainy (June to November). This was in accordance with the observation of Miklic, 1996 that Honeybees do not exit bee hives during rainy days. Adedeji et a,(2014) reported that the best period for hives placement in the Niger Delta region, Nigeria is between August and September since colonization usually occurs around October. The result showed an improvement in the colonization performance in 12,18 and 24 months after installation of hives. Plywood hives installed in the open cocoa farmland accounted for higher colonization percentage than plantation and natural forest. Some factors influencing hive colonization by honeybees include hive types and tree shade management (Kugonza et al., 2008), hive types (Andeet al., 2008), shade tree species types (Babarinde et al., 2011) and hive wood colours (Adedeji and Ayeloja, 2014). In Cocoa farm, both plywood and Danta wood hives recorded 50\% colonization each but the bees later absconded from Danta hive. This was suspected to be as a result of human activities involving the application of insecticides on cocoa trees. Zero $(0 \%)$ colonization was recorded in natural forest for all hives installed during the first six months. This could have been due to unfavorable microclimatic effects on the activities of honeybees during rainy season under a natural forest ecosystem. Kumar et al. (2002) noticed the most intensive honey bee activity during different weather conditions depending on particular investigation site and its weather conditions. The nesting selection of honeybees did not vary from forest to savannah vegetation selecting same family wood members with similar characteristics. Nigeria honeybees have affinity for white and yellow coloured woods over popular brown coloured woods (Aiyeloja and Adedeji, 2014).Plantation forest recorded two hives colonies of 
Danta and Gmelina at different months while one of plywood hive colonized but later absconded. Also, one of plywood hives colonized in Cocoa farm land but later absconded leaving four hives that were not colonized., All the six hives in Natural forest were not colonized during the first seven months (April to October) of the study.

Plywood hives were colonized at $4^{\text {th }}$ and $5^{\text {th }}$ months after installation, followed by Danta hives which were colonized at $5^{\text {th }}$ and $6^{\text {th }}$ months after installation while Gmelina hives were colonized at the $7^{\text {th }}$ month after installation. It was observed in this study that Gmelina colonized late during rainy season contrary to Adedeji and Aiyeloja (2014), who observed colonization rate of $100 \%$ in $G$. arborea and $V$. doniana wood hives within two months of installation in the field in the savanna zone. This could be as a result of the different chemical composition in G. arborea wood (ElMahmood, etal, 2010). The ability of a colony to maintain a high population of foraging worker bees for high honey yield depends on genetically and physiological attributes of the colony as well as response threshold to chemical and social inhibition encountered by the bees (Adeduntan, 2011).

Conclusion: The study has revealed that high colonization potential does not guarantee sustainability of the colony. Sustainability of the colony depends on other external and internal factors within the environment. The study suggests consideration for plywood hive as beekeeping materials in the study area. However, further research work is necessary for the validation of the result. It was also observed that natural forest may not be suitable as apiary during rainy season. It is therefore, suggested to subject plywood hives type to other ecological zones in Nigeria.

Acknowledgments: The authors are grateful to God and to the communities' dwellers that helped in the sample collection in each study area.

\section{REFERENCE}

Adeduntan SA (2011). Influence of Plantation Species on Quality and Quantity of Honey Production. Preceedings of the 34th Annual Conference of the Forestry Association of Nigeria held in Osogbo, Osun State, Nigeria volume 2 pp 310 - 320

Adedeji, GA; Aiyeloja, AA (2014). Preference and Suitability of Nigerian Grown Gmelina arborea Linn. Roxb and Vitex doniana Sweet Woods for Beekeeping in Imeko, Nigeria. International
Journal of Scientific and Engineering Research, 5(5): 1483-1494

Aiyeloja, AA; Adedeji, G A (2014). Preliminary Survey of Wood Species Cavities Preferred By Honeybees in Nigeria. Intern. J.Sci. Engin Res. 5(2): 1313-1320

Ande, A. T; Oyerinde AA; Jibril, M N (2008). Comparative study of the influence of hive types on bee colony establishment. Intern. J. of Agri. and Biol.10: 517-520.

Babarinde, SA; Akanbi, M O Akinpelu,FA; Oyelade, BG; Oyelami, B (2011). Impact of canopy type on honey Bee (Apismelliferaadansonii) (Hymenoptera: Apidae) colony performance and pest infestation. Afr. Sci. 11(3): 169-174.

Eaton, P (2006). Making wax starter strips for top bars. Bees. Develop. J.80: 3-4.

El-Mahmood, AM; Doughari, JH;Kiman H S (2010). In vitro antimicrobial activity of crude leaf and stem bark extracts of Gmelinaarborea (Roxb) against some pathogenic species of Enterobacteriaceae. Afr. J. Pharm Pharmacol. 4: 355.

FAO. (1990). Beekeeping in Africa. Agricultural Services Bulletin Food and Agriculture Organisation of the United Nations Rome. ISBN 92-5-102794-3.96 Pp.

FAO. (2009). State of the World's Forests 2009. Food and Agriculture Organization of the United Nations, Rome.

Franck, P; Garnery, L; Loiseau, A; Oldroyd, BP; Hepburn, HR; Solignac, M; Cornuet, JM (2001). Genetic diversity of the honeybee in Africa: microsatellite and mitochondrial data. Heredity $86,420-430$.

Kumar, M; Singh, R; Chand, H (2002).Foraging activity of Apis ceranaindica and Apis mellifera visiting sunflower (Helianthus annuus L.). Shashpa, 9 (1): 31-34

Noatay, KL (2002). Asia's Useful Trees and Plants. The Tribune News: Monday January 7, 2002, Chandigarh, India.

Miklič,V(1996).Utjecajrazličitihgenotipovaipojedinih klimatskihčinilacanaposetupčelaidrugihpolinator 
aioplodnjusuncokreta, Magistarskateza. Poljoprivrednifakultet Novi Sad. Srbija.

Ruttner, F (1988). Biogeography and Taxonomy of Honeybees. Springer, Berlin, Germany.

Spiewok, S; Neumann, P; Hepburn, HR (2006). Preparation for disturbance- induced absconding of Cape honeybee colonies (Esch.) Apismelliferacapensis. Insect. Soc. 53(1): 27-31.

Tessega, B (2009) Honeybee Production and Marketing Systems, Constraints and Opportunities in Burie District of Amhara Region, Ethiopia. MSc Thesis. Department of Animal Science and Technology. Bahir Dar University, Ethiopia
Vaudo, AD; Ellis JD; Cambray GA, Hill M (2011). The effects of land use on honey bee (Apismellifera) population density and colony strength parameters in the Eastern Cape, South Africa. J. Insect Conserve. 16: 601-611

Warre, A (2007). Beekeeping for All. Pat Cheney and David Heaf, Third edition, UK. 158Pp

Adedeji, GA; Aiyeloja, AA; Larinde, S L; Omokhua, G E (2014). Effect of Seasons on Colonisation and Suitability of Triplochiton Scleroxylon K. Schum. Wood for Beekeeping in Rivers State, Nigeria. Nat Sci. 12(8):117-122

Kugonza, D. R Kamatara, K.B; Nabakabya, D; Kikonyogo, S (2009). Effects of hive type and tree shade on colonization rate and pest prevalence of honeybee (Apis Mellifera) colonies in Central Uganda. Afr. J. Animal. Biomed. Sci. 4 (2): 87-92. 